Illinois State University

ISU ReD: Research and eData

Faculty Publications - Finance, Insurance, and Law

Finance, Insurance, and Law

2010

Inventory Management Effects, Isolated: Evidence from the

Federal Funds Market

Yaman Ö. Erzurumlu

Vladimir Kotomin

Follow this and additional works at: https://ir.library.illinoisstate.edu/fpfil

Part of the Finance and Financial Management Commons 


\title{
Inventory Management Effects, Isolated: Evidence from the Federal Funds Market
}

\author{
Yaman Ömer Erzurumlu \\ Doğuş University, Istanbul, Turkey \\ Vladimir Kotomin \\ University of Wisconsin - Eau Claire
}

Corresponding Author:

Vladimir Kotomin

University of Wisconsin-Eau Claire

College of Business

Department of Accounting and Finance

Eau Claire, WI 54702, U.S.A.

Tel. 1-715-836-3535

Email:kotomin@uwec.edu 


\title{
Inventory Management Effects, Isolated: Evidence from the Federal Funds Market
}

\begin{abstract}
The federal funds market is highly competitive, has uniform information, and does not have most order-processing cost components of equity markets. Hence, it provides an opportunity to study the effect of inventory management on the bid-ask spread in an isolated fashion. Using a unique data set of daily borrowing and lending federal funds quotes posted by a large commercial bank, we find that the bank maintains a fairly constant bid-ask spread throughout a two-week reserve maintenance period. It acts similarly to a market maker facilitating flow of funds between depository institutions throughout the reserve maintenance period. The bank becomes more active toward the end of the period. In particular, on settlement Wednesday it increases the bid and ask quotes relative to the effective federal funds rate in an apparent attempt to manage its reserve inventory and satisfy its own reserve requirements.
\end{abstract}

Keywords: federal funds, bid-ask spread, inventory management 


\section{INTRODUCTION}

Determinants of the bid-ask spread in financial markets discussed in the literature fall into four major categories: inventory management, informational asymmetry, order-processing costs, and competition among market makers. ${ }^{1}$ The federal funds market, where depository institutions trade their reserve balances, has some similarities to exchange markets. However, there are also significant differences. First of all, this market is highly efficient and information is largely uniform. Second, most of the components of order-processing costs in exchange markets, such as an exchange seat price, floor space rent, and informational service cost are not present in the federal funds market. Third, the competitive factor is relatively uniform across the entire market since many institutions engage in facilitation of short-term lending and borrowing between depositories. At the same time, depository institutions in the U.S. must satisfy reserve requirements imposed by the Federal Reserve, which creates the need to manage inventories of reserves. Spindt and Hoffmeister (1988) and Griffiths and Winters (1995) both suggest that the main explanation of the behavior of the federal funds rate is reserve management by depository institutions. Overall, the federal funds market provides a unique environment where the effect of inventory management on the bid-ask spread could be studied in an isolated fashion.

Using a unique data set of daily borrowing (bid) and lending (ask) quotes posted by a large Midwestern U.S. bank trading federal funds for its own account, we study how the quotes and the spread between them evolve throughout the reserve maintenance period. In particular, we examine if and how inventory management necessitated by the federal funds market structure affects the bid-ask spread. To our knowledge, this is the first study that directly investigates the bid-ask spread in the federal funds market.

\footnotetext{
${ }^{1}$ Inventory management deals with inventory control cost or inventory-holding cost. Informational asymmetry is costly because it can lead to adverse selection.
} 
We find that the bank maintains a relatively stable bid-ask spread throughout the twoweek reserve maintenance period, with the bid and ask quotes mimicking a brokered transactionweighted market rate. The bank increases both bid and ask relative to the effective federal funds rate as settlement approaches. This behavior is consistent with the bank maximizing profits and helping to facilitate orderly flow of funds between depository institutions throughout most of the two-week reserve maintenance period while focusing more on its own reserve inventory management through additional borrowing toward the end of the period.

The paper proceeds as follows. The next section provides essential details of the federal funds market and discusses inventory management in the federal funds market. The next section describes data and methods, Section 4 reports and discusses empirical results, and the last section concludes.

\section{INVENTORY MANAGEMENT IN THE FEDERAL FUNDS MARKET}

The U.S. federal funds market is the market for short-term interbank loans, most of which are unsecured. ${ }^{2}$ Its primary purpose is to trade funds to satisfy depository institutions' reserve requirements (set by Regulation D of the Federal Reserve). Depository institutions can satisfy the requirements either by holding balances at the Federal Reserve Bank or by vault cash. A reserve maintenance period starts on Thursday and ends on Wednesday two weeks later (settlement Wednesday). On settlement Wednesday, depositories compare their actual reserves to total required reserves. Depository institutions must satisfy their reserve requirement each period; however, a small amount of excess or deficiency may be carried over to the next period. No

\footnotetext{
${ }^{2}$ Some federal funds loans are explicitly secured. In a secured transaction, the borrower places government securities in a custody account for the lender as collateral to support the loan. The borrower retains title to the securities (which is different from a repurchase agreement in which pledged securities change ownership). Lending institutions sometimes request secured transactions (Goodfriend and Whelpley 1993). The bid and ask quotes employed in this study are for unsecured transactions.
} 
institution can carry over a deficiency two maintenance periods in a row. Toward the end of the maintenance period some institutions may face pressure to adjust the amount of their reserves based on the required level; they achieve it by borrowing funds from other institutions or lending excess reserves. Reserve balances also count for weekends and holidays when the market is closed. $^{3}$

When funds are transmitted, the lending bank's account with the Federal Reserve Bank is debited, thus reducing the amount of reserves, and the borrowing bank's account is credited, increasing the amount of reserves. The opposite happens when the loan is repaid. Transactions in the federal funds market may be carried in three ways. First, funds may be transacted directly between institutions that have pre-approved lines of credit with each other. Second, fed funds may be traded through brokers, non-banks that facilitate trades but do not take positions. The brokers' market is only available to banks that trade in volume; a round lot is $\$ 5$ million, and transactions involving hundreds of millions of dollars are not uncommon (Stigum and Crescenzi 2007). Third, banks may transact through correspondent banks. Correspondent banks are often thought to upstream funds from small banks, but they trade on both sides of the market. Smaller banks often prefer to act through correspondents because they are unable to trade in the brokered market. Quoting Stigum and Crescenzi (2007, pp.511-512), “To cultivate correspondents that will sell funds to them, large banks stand ready to buy whatever sums these banks offer, whether they need all these funds or not. If they get more funds than they need, they sell off the surplus in the brokers' market. Also, they will sell to their correspondents if the correspondents need funds, but that occurs infrequently." To indicate at what rates they are ready to borrow from or lend to other institutions, larger banks quote borrowing (bid) and lending (ask) rates. By regularly

\footnotetext{
${ }^{3}$ Having insufficient reserves entails pecuniary and, more importantly, non-pecuniary penalties in the form of regulators' scrutiny. Having excess reserves involved an opportunity loss since (required and excess) reserve balances did not earn interest during our sample period.
} 
trading federal funds, these institutions facilitate the flow of funds between depositories. Each time such an institution transacts with a client by borrowing (lending) funds, its inventory of funds and its reserves increase (decrease). Therefore, it always trades for its own account and has to constantly monitor and manage its inventory of funds and reserves. It may do so by adjusting the bid and ask quotes. The main data utilized in this study are daily bid and ask quotes of a large Midwestern U.S. bank that trades federal funds for its own account and serves as a correspondent institution for many smaller banks in its region.

Of the major determinants of the bid-ask spread in financial markets - inventory management, informational asymmetry, order-processing cost, and competition among market makers - only inventory management plays an important role in the federal funds market because periodic settlement with the Fed requires a certain degree of inventory management by depository institutions. The Spindt and Hoffmeister (1988) model predicts that (1) the variance of the federal funds rate increases on days before nontrading days and peaks on settlement days and (2) the intraday variance peaks at the end of the day. Griffiths and Winters (1995) confirm predictions of Spindt and Hoffmeister (1988) and show that profit-maximizing institutions tend to build a reserve deficiency rather than a surplus throughout most of the reserve maintenance period. ${ }^{4}$ They also provide evidence of lending pressure before non-trading days and suggest that this is a result of the federal funds market structure. Both Spindt and Hoffmeister (1988) and Griffiths and Winters (1995) suggest that inventory control (reserve management) by depository institutions is the explanation for the behavior of the federal funds rate's level and variance. Cyree and Winters (2001) conclude that the reverse-J intraday pattern in the federal funds rate is caused by inventory management necessitated by end-of-day trading stoppages, consistent with

\footnotetext{
${ }^{4}$ Stigum and Crescenzi (2007, p.500) resonate with this conclusion: "By 1960... the big New York and Chicago banks began to deliberately operate their basic money positions so that they were always short, on the grounds that they needed room to buy all the fed funds that were coming into them from smaller correspondents."
} 
the model of Brock and Kleidon (1992). Clouse and Dow (2002) use dynamic programming to model bank demand for reserves throughout the maintenance period. Their model predicts an upward trend in demand for reserves throughout the maintenance period, lower demand on Fridays, and a spike in demand on settlement Wednesday. Carpenter and Demiralp (2006) find that the liquidity effect of the Fed's open market operations is highest on settlement Wednesday. This result is expected because reserve deficiencies cannot be shifted (except for a small carryover provision) to the next maintenance period; it is consistent with the model of Clouse and Dow (2002). In this study, we expect the bid quote to increase and the bid-ask spread either to narrow or stay unchanged as settlement approaches and the bank attempts to cover its own reserve shortages by borrowing at a higher rate.

\section{DATA AND METHODS}

\subsection{Data}

The data comprise the daily lending (ask) and borrowing (bid) quotes of an institution trading federal funds for its own account (a large Midwestern U.S. commercial bank). The daily quotes are available for the period from February 2, 2001 through September 10, 2001. The total number of trading days is 154 . There are 16 settlement Wednesdays as well as Tuesdays before settlement Wednesdays (second Tuesdays hereafter), 33 days preceding non-trading days (32 Fridays and one Tuesday), and 33 days following non-trading days (29 Mondays, three Tuesdays, and one Thursday) in our sample period. While the sample period is short, this is the only data of this type that is available. To our knowledge, this is the first study that uses a bidask spread in the federal funds market. 
We also collect the effective federal funds rate series (EFFR hereafter) from the Federal Reserve H15 report. The EFFR is a weighted average of rates on brokered trades reported by the federal funds brokers to the Federal Reserve. It is calculated by the Federal Reserve Bank of New York.

\subsection{Methodology and hypotheses}

We start by studying the dynamics of rate changes throughout a two-week reserve maintenance period, after which we present and discuss regression results. To identify and highlight various aspects of the intra-period behavior of rates and quotes, we employ the following seven dependent variables in our analysis: the EFFR, the bank's bid quote, the bank's ask quote, the spread between the quotes (bid-ask spread), the difference between the bid quote and the EFFR, the difference between the ask quote and the EFFR, and the difference between the bid-ask midpoint and the EFFR. Table 1 contains means of the dependent variables on each day of the two-week reserve maintenance period.

\section{[Insert Table 1 here]}

Table 1 allows us to make several interesting observations. First, the bid-ask spread is fairly constant throughout the reserve maintenance period at around 28 basis points. It narrows down slightly toward the end of the period. Second, the ask quote is on average 29 basis points above the EFFR, while the bid quote is on average one basis point above the EFFR. It suggests that the bank only wants to play on the borrowing side of the market, which is consistent with the behavior of most large banks in the fed funds market (Griffiths and Winters, 1995). This bank will only lend funds if other (typically smaller) institutions are willing to pay 29 basis points above the EFFR. (Recall that the EFFR is the average rate in the brokered fed funds market, 
which is characterized by large transactions that are out of reach of small banks.) ${ }^{5}$ Third, the last three variables presented in the table (the bid minus the EFFR, the ask minus the EFFR, and the bid-ask midpoint minus the EFFR) increase over the last three days of the reserve maintenance period with peaks on settlement Wednesday. This is consistent with inventory and reserve management gaining importance as settlement approaches. The bank appears to be more active on the bid side of the market and it manages inventory by continually borrowing fed funds with additional borrowing at settlement. Finally, the behavior of the EFFR is consistent with the findings of previous research: increases after non-trading days (Mondays), decreases before nontrading days (Fridays) and before settlement. The decrease before settlement is a relatively recent phenomenon that was apparently brought into existence by the switch from contemporaneous reserve requirements (CRR) to lagged reserve requirements (LRR) in 1998 (Kotomin and Winters 2007). The reserve computation period under LRR starts 30 days before the reserve maintenance period. Under CRR, there were only two days between the ends of the computation and maintenance periods. The switch from CRR to LRR eliminated one major source of uncertainty for depositories by allowing them to compute the required reserves prior to the start of the maintenance period. Another major source of uncertainty, deposits and withdrawals of funds by customers, is still present, of course. This is why large, efficient banks may still tend to hold less reserves in the beginning of the reserve maintenance period and cover the shortage toward the end of the period. Occasional liquidity squeezes are therefore possible on settlement Wednesday. However, most banks may adjust their reserve balances a day or two before settlement; as a result, we observe a softening in the federal funds rate on second Tuesday and settlement Wednesday. Overall, the behavior of the EFFR summarized in Table 1 is

\footnotetext{
${ }^{5}$ Allen and Saunders (1986) show that small banks are constrained in their ability to borrow federal funds due to their size and location. As a result, small banks generally pay higher rates in the federal funds market.
} 
representative of an average bank, while the evolution of the bank's bid and ask quotes employed in this study is consistent with the behavior of a large, efficient bank that minimizes the cost of holding reserves throughout the reserve maintenance period (Griffiths and Winters 1995, Clouse and Dow 2002).

To determine if the intraperiod changes discussed above are statistically significant, we use regression analysis. We start with the following OLS regression with the White's adjustment for heteroskedasticity for each of the dependent variables:

$$
y_{t}=\alpha_{0}+\alpha_{1} 1 s t T h+\alpha_{2} D B N T B+\alpha_{3} D A N T B+\alpha_{4} \operatorname{Sec} T+\alpha_{5} \operatorname{Set} W+e_{t}
$$

where

$y_{t}=\quad$ the dependent variable (EFFR, bid quote, ask quote, bid-ask spread, bid minus EFFR, ask minus EFFR, or bid-ask midpoint minus EFFR)

$1 s t T h=$ the dummy variable equal to 1 on the first Thursday of the reserve maintenance period and 0 otherwise;

$D B N T B=$ the dummy variable equal to 1 on days before non-trading days and 0 otherwise; it covers all Fridays plus Tuesday, July 3, 2001;

$D A N T B=$ the dummy variable equal to 1 on days after non-trading days and 0 otherwise; it covers all Mondays plus three Tuesdays after long weekends (February 20, May 29, and September 4, 2001) and Thursday, July 5, 2001;

$\operatorname{Sec} T=$ the dummy variable equal to 1 on second Tuesday and 0 otherwise;

Set $W=$ the dummy variable equal to 1 on settlement Wednesday and 0 otherwise. $^{6}$

We follow Griffiths and Winters (1995) and Kotomin and Winters (2007) in our choice of independent variables. ${ }^{7}$ To test for autocorrelation, we look at the Durbin-Watson statistic and

\footnotetext{
${ }^{6}$ We allowed the DANTB and SecT dummies to overlap. If the last day of a reserve maintenance period fell on Tuesday due to a holiday, that Tuesday would have been coded as settlement Wednesday. However, there were no such occurrences in our sample.

${ }^{7}$ Griffiths and Winters (1995) only worked with full maintenance periods that had all 10 trading days. They did it because the days around long weekends and one-day holidays had special pressures, like Fridays and Mondays, but sometimes even more so. We cannot afford to remove several reserve maintenance periods due to the short duration of our sample period.
} 
run the Breusch-Godfrey serial correlation LM test. If the null of no autocorrelation is rejected by the test, we extend the basic model to an ARMA model. If so, we test for stationarity using the augmented Dickey-Fuller test. We then proceed to estimate ARMA models for stationary series. For the series whose nonstationarity cannot be rejected, we estimate ARIMA models with the first differences of the corresponding series as dependent variables. To choose the correct specification, we use the lowest AIC values and also check if the residuals are white noise. AR(I)MA models take the following form:

$$
y_{t}=b_{0}+b_{1} 1 s t T h+b_{2} D B N T D+b_{3} D A N T D+b_{4} \operatorname{Sec} T+b_{5} \operatorname{Set} W+\sum_{i=1}^{p} \rho_{1} y_{t-i}+\sum_{j=1}^{q} \theta_{j} \hat{u}_{t-j}+\varepsilon_{t}
$$

The correct ARMA or ARIMA models are then tested for possible ARCH effects using the $\mathrm{ARCH}-\mathrm{LM}$ test. If the null hypothesis of no $\mathrm{ARCH}$ effect is rejected, the model is extended to an ARCH or GARCH model. Equation (2) becomes the mean equation for a $(\mathrm{G}) \mathrm{ARCH}(\mathrm{m}, \mathrm{n})$ model and Equation (3) below is the variance equation:

$$
h_{t}=\omega+c_{1} 1 s t T h+c_{2} D B N T D+c_{3} D A N T D+c_{4} \operatorname{Sec} T+c_{5} \operatorname{Set} W+\sum_{i=1}^{m} \alpha_{i} \hat{u}_{t-i}^{2}+\sum_{j=1}^{n} \beta_{j} h_{t-j}
$$

The number of $\mathrm{ARCH}$ and GARCH terms in the variance equation ( $m$ and $n$ ) is chosen by the lowest AIC.

If the bank's primary motivation is to help facilitate flow of funds, the bid and ask quotes will closely follow the EFFR. Alternatively, the bank might deviate from the market in order to (i) maximize profits by increasing the spread either through lending at a higher rate or borrowing at a lower rate (or both) or (ii) manage its own inventory by increasing the bid (ask) rate and/or lowering the ask (bid) rate. Since larger depository institutions tend to run a reserve deficiency throughout most of the maintenance period (Griffiths and Winters 1995), they trade to cover reserve shortages toward the end of the period. Therefore, a simultaneous increase in the bid and 
ask quotes relative to the EFFR is consistent with the bank managing its reserves inventory more actively on second Tuesday and/or settlement Wednesday. An increase in the bid without an equally large (or any) increase in the ask relative to the effective federal funds rate is also consistent with inventory and reserve management by the bank. Accordingly, we expect the bid quote to increase relative to the EFFR and the bid-ask spread either to narrow or stay unchanged as settlement approaches. We also expect the pattern documented in the literature to show up: the EFFR, as well as the trading bank's bid and ask quotes, decrease on days before non-trading days (e.g., Fridays) due to sell-side pressure and increase on days after non-trading days (e.g., Mondays) due to reserve rebalancing.

\section{EMPIRICAL RESULTS}

First, for all but one regressions of form (1) the Breusch-Godfrey serial correlation LM test rejects the null of no autocorrelation (the bid-ask spread regression is the exception). For these models, we ran the AR(I)MA models with the optimal number of AR and MA terms ( $p$ and $q$ ) as determined by AIC. Second, the augmented Dickey-Fuller test suggests that the series representing differences (the bid-ask spread, the bid quote minus the EFFR, the ask quote minus the EFFR, and the bid-ask midpoint minus the EFFR) are stationary. Not surprisingly, the null of nonstationarity could not be rejected for the series representing rates or quotes (the EFFR, the bid quote, and the ask quote). Accordingly, we use first differences (daily changes) of the nonstationary series as dependent variables (consequently, these are ARIMA models). We then test the AR(I)MA models for the ARCH effect. The ARCH-LM test rejects the null of no ARCH effect in the model for the difference between the bid quote and the EFFR; $\operatorname{GARCH}(3,1)$ is the optimal specification for it. The test suggests no ARCH effect in the remaining models. 
Table 2 reports the main results of the estimations. The pattern is consistent with the motivation to lend excess reserves prior to settlement Wednesdays and non-trading days (Griffiths and Winters 1995). The EFFR declines on days before non-trading days, second Tuesdays, and settlement Wednesdays. The declines on second Tuesdays and settlement Wednesdays are consistent with the results of Kotomin and Winters (2007). The EFFR increases on days after non-trading days, likely due to the abatement of the pre-weekend (pre-holiday) sellside pressure, large institutions' tendency to build an accumulated reserve deficiency rather than a surplus, and their desire to rebalance their reserves as the market opens after non-trading days (Griffiths and Winters 1995). The pressure resulting from idiosyncratic information accumulated by institutions over the non-trading days could be partially responsible for this reversion.

[Insert Table 2 here]

The changes in the bank's bid and ask quotes follow the changes in the EFFR closely throughout most of the reserve maintenance period and have the same signs on the days on which at least one of these three variables shows statistically significant changes (days before and after non-trading days, second Tuesday, and settlement Wednesday). However, the bid change on settlement Wednesday is not statistically significant.

The differences between the bid or ask quote and the EFFR reveal more about behavior of the bank. These variables remain statistically unchanged for all days except settlement Wednesday, when the difference between the bid and the EFFR increases by 4.9 basis points (significant at the 1\% level) and the difference between the ask and the EFFR increases by 3.7 basis points (significant at the $10 \%$ level). The bid-ask midpoint increases by 3.8 basis points (significant at the 5\% level) over the EFFR on settlement Wednesdays. This behavior of the bid and ask quotes relative to the EFFR is consistent with the bank attempting to borrow more to satisfy its reserve requirements and, to a degree, discourage borrowing from it by other banks 
before settlement. Given that the increase in the ask relative to the EFFR is only marginally statistically significant, it appears that the bank manages the bid quote in a more consistent manner (by consistently increasing it relative to the EFFR on settlement Wednesdays) than the ask quote. $^{8,9}$

The results reported in Table 2 suggest that the bank becomes more active toward the end of the reserve maintenance period. In particular, the increases of the bank's bid quote and the bid-ask midpoint over the EFFR on settlement Wednesday suggest that the bank focuses more on covering its own reserve shortages accumulated throughout the period. This behavior is consistent with the idea that large, highly efficient banks prefer to run a reserve deficiency throughout most of the reserve maintenance period and cover their reserve shortages late in the period (Griffiths and Winters 1995, Clouse and Dow 2002). Moreover, since the bank is more active on the bid side of the market, it tends to manage its federal funds inventory by additional borrowing at settlement. At the same time, it does not mind lending to depositories willing to pay a relatively high ask rate on settlement Wednesday. The higher ask (relative to the EFFR) may also be viewed as somewhat of a discouragement to borrow from the bank on settlement Wednesday. The finding that the bank's bid-ask spread does not significantly change throughout the maintenance period while the bid and ask rates do (relative to the EFFR) is consistent with the inventory management models of Stoll (1978), Amihud and Mendelson (1980), and Ho and Stoll (1981), all of which conclude that inventory management would affect the placement of the spread but not its size. ${ }^{10}$ On the empirical side, our results are consistent with the finding of Chan, Christie, and Schultz (1995) that NASDAQ dealers post quotes attracting trades on only

\footnotetext{
${ }^{8}$ The bank changed the bid and ask quotes (relative to the EFFR) in the same direction on 12 out of 16 settlement Wednesdays during our sample period. It tended to increase the bid quote relative to the EFFR (11 out of 16 settlement Wednesdays saw increases) more often than the ask quote relative to the EFFR (nine times out of 16). ${ }^{9}$ We ran different model specifications (OLS, AR(I)MA, (G)ARCH) for all dependent variables to check robustness. The results remain qualitatively similar.

${ }^{10}$ Chapter 2 in O'Hara (1995) provides a summary of these and other inventory management models.
} 
one side of the spread and limiting exposure to trades that would lead to unwanted inventory

positions toward the end of a trading day. Our findings can also be considered consistent with the results of Carpenter and Demiralp (2006) who essentially find that the federal funds market is more sensitive to changes in liquidity on settlement Wednesday. ${ }^{11}$

\section{CONCLUSION}

Among the four components of the bid-ask spread discussed in the literature - orderprocessing costs, inventory management, asymmetric information, and competition among market makers - only inventory management can play a major role in the federal funds market due to its structure. Depository institutions are forced to manage their reserves on a regular basis; they have to achieve an optimal level of reserves every other Wednesday (settlement Wednesday). Thus, the federal funds market's unique structure allows to isolate the impact of inventory management on the bid-ask spread from the impact of other factors.

Analyzing a unique data set of bid and ask quotes of a large commercial bank that actively trades federal funds for its own account, we find that the bank maintains a fairly constant bid-ask spread throughout a two-week reserve maintenance period. The bank becomes more active toward the end of the period. In particular, on settlement Wednesday it raises the bid quote and, to a lesser extent, the ask quote relative to the brokered-transaction weighted effective

\footnotetext{
${ }^{11}$ Not controlling for changes in the target federal funds rate (TFFR) may contaminate the results somewhat. The Fed made five changes in the TFFR during our sample period, all of them reductions. Two occurred on second Tuesdays, two on settlement Wednesdays, and one on Monday. We ran two different model specifications with the TFFR change dummy - with the dummy covering only the day of the change and the dummy covering the day before and the day of the change (quite often, financial market participants anticipate a TFFR change before an upcoming FOMC meeting). Under either specification, the TFFR coefficient is significant and the fit improves for the regressions where the dependent variables represent changes in rates and quotes (EFFR, bid, and ask), while the coefficient is insignificant and the fit deteriorates for the rest of the regressions (bid-ask spread, bid minus EFFR, ask minus EFFR, and bid-ask midpoint minus EFFR). The magnitude and significance of all other coefficients in all regressions do not change. We decided not to report these results in the paper and keep the same regressors in all seven models.
} 
federal funds rate. It suggests that the bank prefers to manage its inventory by more actively adjusting the borrowing rate. It is consistent with the federal funds market being affected by depository institutions' inventory management on settlement Wednesdays. The changes in the bid and ask quotes of the bank around non-trading days are consistent with the pattern previously documented in the literature. Overall, our findings suggest that the bank acts similarly to a market maker who maintains orderly flow of funds throughout the reserve maintenance period. The bank's own reserve management considerations prompt it to borrow funds at a higher rate and discourage borrowing from it by other institutions by setting a higher ask rate (both relative to the effective federal funds rate) on settlement Wednesday. 


\section{REFERENCES}

Allen, L. and Sanders, A., 1986, The large-small bank dichotomy in the federal funds market, Journal of Banking and Finance 10, 219-230

Amihud, Y., and Mendelson, H., 1980, Dealership market: market making with inventory, Journal of Financial Economics 8, 31-53.

Brock, W. and Kleidon, A., 1992, Periodic market closure and trading volume: A model of intraday bids and asks, Journal of Economic Dynamics and Control 16, 451-489

Carpenter, S. and Demiralp, S., 2006, The liquidity effect in the federal funds market: Evidence from daily open market operations, Journal of Money, Credit, and Banking 38, 901-920.

Chan, K., Christie, W., and Schultz, P., 1995, Market structure and the intraday pattern of bidask spreads for NASDAQ securities, Journal of Business 68, 35-60.

Clouse, J. and Dow, J., 2002, A computational model of banks' optimal reserve management policy, Journal of Economic Dynamics and Control 26, 1787-1814.

Cyree, K. and Winters, D., 2001, An intraday examination of the federal funds market: implications for the theories of the reverse-J pattern, Journal of Business 74, 535-556.

Goodfriend, M. and Whelpley, W., 1993, Federal Funds, Chapter 2 in Instruments of the Money Market, Federal Reserve Bank of Richmond, 1998; available at http://richmondfed.org/publications/research/special_reports/instruments_of the money market/pdf/full_publication.pdf.

Griffiths, M. and Winters, D., 1995, Day-of-the-week effects in federal funds rates: Further empirical findings, Journal of Banking and Finance 19, 1265-1284

Ho, T., and Stoll, H., 1981, Optimal dealer pricing under transactions and return uncertainty, Journal of Financial Economics 9, 47-73

Kotomin, V. and Winters, D., 2007, The impact of the return to lagged reserve requirements on the federal funds market, Journal of Economics and Business 59, 111-129

O’Hara, M., 1995, Market Microstructure Theory, Blackwell.

Spindt, P. and Hoffmeister, J., 1988, The micromechanics of the federal funds market: Implications for day-of-the-week effects in funds rate variability, Journal of Financial and Quantitative Analysis 23, 401-416.

Stigum, M., and Crescenzi, A., 2007, Stigum's money market, $4^{\text {th }}$ edition, McGraw-Hill.

Stoll, H., 1978, The supply of dealer services in securities markets, Journal of Finance 33, 11331151. 
Table 1. Means of Dependent Variables Throughout the Reserve Maintenance Period

\begin{tabular}{|c|c|c|c|c|c|c|c|}
\hline Day & EFFR & Bid & Ask & Spread & Bid-FF & Ask-FF & Mid-FF \\
\hline \hline $1^{\text {st }}$ Thu & 4.39 & 4.39 & 4.67 & 28.4 & 0.2 & 28.6 & 14.4 \\
$1^{\text {st }}$ Fri & 4.32 & 4.34 & 4.62 & 27.9 & 1.9 & 29.7 & 15.8 \\
$1^{\text {st }}$ Mon & 4.37 & 4.37 & 4.65 & 28.1 & 0.1 & 28.2 & 14.1 \\
$1^{\text {st }}$ Tue & 4.37 & 4.39 & 4.67 & 27.6 & 2.3 & 29.9 & 16.1 \\
$1^{\text {st }}$ Wed & 4.45 & 4.44 & 4.71 & 26.9 & -1.0 & 25.9 & 12.4 \\
$2^{\text {nd }}$ Thu & 4.50 & 4.50 & 4.77 & 27.8 & -0.2 & 27.6 & 13.7 \\
$2^{\text {nd }}$ Fri & 4.47 & 4.47 & 4.75 & 28.0 & -0.3 & 27.7 & 13.7 \\
$2^{\text {nd }}$ Mon & 4.71 & 4.72 & 4.99 & 26.9 & 1.7 & 28.7 & 15.0 \\
$2^{\text {nd }}$ Tue & 4.42 & 4.44 & 4.71 & 27.6 & 1.7 & 29.4 & 15.6 \\
Set. Wed. & 4.35 & 4.40 & 4.67 & 27.2 & 4.3 & 31.5 & 17.9 \\
\hline All days & 4.41 & 4.42 & 4.70 & 27.7 & 1.0 & 28.7 & 14.9 \\
\hline Units & $\%$ & $\%$ & $\%$ & bp & bp & bp & bp \\
\hline
\end{tabular}

Note: The variables whose means are reported in the table are (1) the effective federal funds rate (EFFR), (2) the bank's bid quote, (3) the bank's ask quote, (4) the bank's bid-ask spread, (5) the difference between the bank's bid quote and the EFFR, (6) the difference between the bank's ask quote and the EFFR, and (7) the difference between the bid-ask midpoint and the EFFR. The first three variables are measured in percentage points, the last four - in basis points. 
Table 2 Estimation Results.

\begin{tabular}{|c|c|c|c|c|c|c|c|}
\hline DV/IV & EFFR & Bid & Ask & Spread & $\begin{array}{c}\text { Bid- } \\
\text { EFFR }\end{array}$ & $\begin{array}{c}\text { Ask- } \\
\text { EFFR }\end{array}$ & $\begin{array}{l}\text { Midpt- } \\
\text { EFFR }\end{array}$ \\
\hline Intercept & $\begin{array}{c}-1.5 \\
(-1.27)\end{array}$ & $\begin{array}{c}-0.8 \\
(-0.70)\end{array}$ & $\begin{array}{c}-0.3 \\
(-0.26)\end{array}$ & $\begin{array}{c}27.4 * * * \\
(7.51)\end{array}$ & $\begin{array}{c}0.5 \\
(0.82)\end{array}$ & $\begin{array}{c}28.1 * * * \\
(42.24)\end{array}$ & $\begin{array}{c}14.4 * * * \\
(23.81)\end{array}$ \\
\hline $1^{\text {st }}$ Thu & $\begin{array}{l}7.9 * * * \\
(3.04)\end{array}$ & $\begin{array}{c}0.0 \\
(0.0)\end{array}$ & $\begin{array}{c}-1.2 \\
(-0.38)\end{array}$ & $\begin{array}{c}1.0^{*} \\
(1.70)\end{array}$ & $\begin{array}{c}0.0 \\
(0.0)\end{array}$ & $\begin{array}{c}0.5 \\
(0.40)\end{array}$ & $\begin{array}{c}0.1 \\
(0.05)\end{array}$ \\
\hline DBNTD & $\begin{array}{l}-3.5 * * \\
(-2.41)\end{array}$ & $\begin{array}{l}-4.1 * * \\
(-2.02)\end{array}$ & $\begin{array}{l}-5.4 * * \\
(-2.53)\end{array}$ & $\begin{array}{c}0.6 \\
(0.90)\end{array}$ & $\begin{array}{c}0.8 \\
(0.79)\end{array}$ & $\begin{array}{c}1.2 \\
(1.15)\end{array}$ & $\begin{array}{c}1.1 \\
(0.97)\end{array}$ \\
\hline DANTD & $\begin{array}{l}8.0 * * * \\
(5.48)\end{array}$ & $\begin{array}{c}6.2 * * * \\
(2.99)\end{array}$ & $\begin{array}{c}6.0 * * * \\
(4.37)\end{array}$ & $\begin{array}{c}0.3 \\
(0.66)\end{array}$ & $\begin{array}{c}-0.2 \\
(-0.27)\end{array}$ & $\begin{array}{c}-0.1 \\
(-0.15)\end{array}$ & $\begin{array}{c}-0.2 \\
(-0.30)\end{array}$ \\
\hline $2^{\text {nd }}$ Tue. & $\begin{array}{c}-9.7 * * * \\
(-4.05)\end{array}$ & $\begin{array}{l}-6.5 * * \\
(-2.11)\end{array}$ & $\begin{array}{l}-6.3 * * \\
(-1.99)\end{array}$ & $\begin{array}{c}0.2 \\
(0.28) \\
\end{array}$ & $\begin{array}{c}0.5 \\
(0.44) \\
\end{array}$ & $\begin{array}{c}1.6 \\
(1.36) \\
\end{array}$ & $\begin{array}{c}1.4 \\
(1.31) \\
\end{array}$ \\
\hline Set. Wed. & $\begin{array}{l}-6.4 * * \\
(-2.03)\end{array}$ & $\begin{array}{c}-3.7 \\
(-1.28) \\
\end{array}$ & $\begin{array}{c}-4.3^{*} \\
(-1.76) \\
\end{array}$ & $\begin{array}{c}-0.2 \\
(-0.29) \\
\end{array}$ & $\begin{array}{c}4.9 * * * \\
(3.93) \\
\end{array}$ & $\begin{array}{c}3.7^{*} \\
(1.86) \\
\end{array}$ & $\begin{array}{l}3.8^{* *} \\
(2.26) \\
\end{array}$ \\
\hline Adj. $R^{2}$ & .357 & .248 & .239 & .089 & N/A & .251 & .239 \\
\hline \# of obs. & 154 & 154 & 154 & 154 & 154 & 154 & 154 \\
\hline $\begin{array}{l}\text { Model } \\
\text { Spec. }\end{array}$ & $\begin{array}{c}\text { ARIMA } \\
(3,1,4)\end{array}$ & $\begin{array}{c}\text { ARIMA } \\
(4,1,3)\end{array}$ & $\begin{array}{c}\text { ARIMA } \\
(3,1,4)\end{array}$ & $\begin{array}{c}\text { OLS } \\
\text { (White) }\end{array}$ & $\begin{array}{c}\text { GARCH } \\
(3,1)\end{array}$ & $\begin{array}{c}\text { ARMA } \\
(1,2)\end{array}$ & $\begin{array}{c}\text { ARMA } \\
(1,2)\end{array}$ \\
\hline DV Spec. & $1^{\text {st }}$ DIFF & $1^{\text {st }}$ DIFF & $1^{\text {st }}$ DIFF & LEVEL & LEVEL & LEVEL & LEVEL \\
\hline
\end{tabular}

Note: Coefficients are in basis points, t-statistics are in parentheses below the coefficients. We use the first difference as a dependent variable in the equations for the EFFR, bid quote, and ask quote because these series are nonstationary.

$* * *, * *, *$ indicate significance at the $1 \%, 5 \%$, and $10 \%$ level, respectively. 